\title{
Sod Competition in Peach Production: I. Managing Sod Proximity
}

\author{
D.M. Glenn ${ }^{1}$ and W.V. Welker ${ }^{2}$ \\ U.S. Department of Agriculture-Agricultural Research Service, Appalachian Fruit Research Station, 45 \\ Wiltshire Road, Kearneysville, WV 25430 \\ George M. Greene ${ }^{3}$ \\ Pennsylvania State University-Fruit Research and Extension Center, P.O. Box 309, University Drive, \\ Biglerville, PA 17307-0309
}

Additional index words. Prunus persica, irrigation, fertilization, winter hardiness, nutrition, orchard floor management, yield efficiency

\begin{abstract}
Mature peach trees were grown in six different-sized vegetation-free areas (VFAs) $\left(0.36\right.$ to $\left.13 \mathrm{~m}^{2}\right)$ with and without stage 3 drip irrigation for 6 years. As VFA size increased, so did the trunk cross-sectional area, canopy diameter, total yield/tree, large fruit yield/tree, and pruning weight/tree. The yield efficiency of total fruit and large fruit initially increased with the increasing size of VFAs and then remained stable over the range of VFAs. Applying supplemental irrigation increased yield of large fruit and leaf $N$ percentage in all VFAs. Cold hardiness was not affected by VFA size or irrigation treatment. The smaller VFAs resulted in smaller, equally efficient trees. Sod management was an effective, low-cost approach to controlling peach tree size, and, when combined with irrigated, high-density production, potentially increased productivity.
\end{abstract}

The purpose of our study was to evaluate long-term sod management and supplemental irrigation on the nutrition, yield, and yield efficiency of peach. The factors most cited as limiting highdensity peach production are excessive vegetative growth in peach and the associated canopy shading problems (Chalmers et al., 1981; Giulivo et al., 1984; Hayden and Emerson, 1973). However, high-density peach systems have the potential for high, early yield and economic return (Phillips and Weaver, 1975). Research has demonstrated success in developing high-density peach systems (Bargioni et al., 1983; Chalmers et al., 1981; Hutton et al., 1987; Williamson and Coston, 1990). However, to improve the efficiency of these systems, research continues to identify genetic and cultural methods that control tree vigor. The following four approaches have limited tree size.

1) Dwarfing rootstocks can reduce tree size as much as $50 \%$ (Layne, 1987); however, other studies do not indicate a wide range of tree size control in peach (Dozier, 1984; Rom, 1983).

2) Scorza (1984) suggested that the semi-dwarf growth habit has the most potential for high-density peach plantings. Gradziel and Beres (1993) have developed a semi-dwarf clingstone peach, with $30 \%$ to $50 \%$ reduction in internode length, that may thrive in high-density systems.

3) Plant growth regulators can control tree size (Miller, 1988); however, environmental concerns limit their development in the United States.

4) Chalmers et al. (1981) used regulated deficit irrigation (RDI) to control tree size in plantings of 4166 trees/ha and maintained high productivity. Chalmers et al. (1981) and Ran et al. (1992)

Received for publication 25 Aug. 1995. Accepted for publication 19 Jan. 1996 Research conducted at USDA-ARS, Kearneysville, WV. Use of trade names does not imply endorsement of the products named, nor criticism of similar ones not named. The cost of publishing this paper was defrayed in part by the payment of page charges. Under postal regulations, this paper therefore must be hereby marked advertisement solely to indicate this fact.

${ }^{1}$ Soil scientist.

${ }^{2}$ Weed scientist.

${ }^{3}$ Pomologist. limited root growth to the wetted area of irrigation and limited tree vigor. Boland et al. (1994) achieved a 4-fold difference in size for peach trees planted in isolated soil volumes ranging from 0.025 to $1.0 \mathrm{~m}^{3}$.

In temperate regions, root growth is not exclusively limited to the soil volume wetted by irrigation, and RDI would not sufficiently limit root growth. Other cultural approaches are needed to control tree size in temperate and subhumid regions. Williamson and Coston (1990) and Myers (1992) controlled tree vigor in a subhumid region by lining the lower extent of the rootzone with a fabric. Welker and Glenn $(1985,1989)$ used sod competition to control tree size in young peach trees, and Huslig et al. (1993) used sod competition to limit vegetative growth before stage 3 of fruit development and then killed the sod to prevent reduced fruit size. The work of Welker and Glenn $(1985,1989)$ and Huslig et al. (1993) demonstrated that sod competition reduced leaf $\mathrm{N}$ levels. High leaf $\mathrm{N}$ and late-season $\mathrm{N}$ fertilization have been related to increased susceptibility to cold inquiry (Chandler, 1954; Cooper, 1953; Crane, 1930), and early work suggested that cover crops that decreased the growth in late summer increased cold hardiness (Bradford and Cardinell, 1926). Managed sod competition to control tree size has potential for high-density peach plantings and allows flexibility in using rootstocks adapted to local conditions. The specific objectives of this study were to 1) evaluate the longterm effect of six vegetation-free areas (VFAs) and stage 3 irrigation and fertigation on peach tree growth and yield components and 2) evaluate the effect of VFAs and irrigation on peach tree cold hardiness in light of the potential to reduce $\mathrm{N}$ uptake.

\section{Materials and Methods}

Our present study occurred from 1987 through 1992, continuing earlier work (Welker and Glenn, 1985, 1989) using the same field study. In April 1983, uniform-size 'Loring' trees (1.0-cm trunk diameter) on Halford seedling rootstock were planted in hand-dug holes $60 \mathrm{~cm}$ deep in 'Kentucky 31' (K-31) tall fescue sod (Festuca arundinaceae Schreb). All trees were pruned to a height 


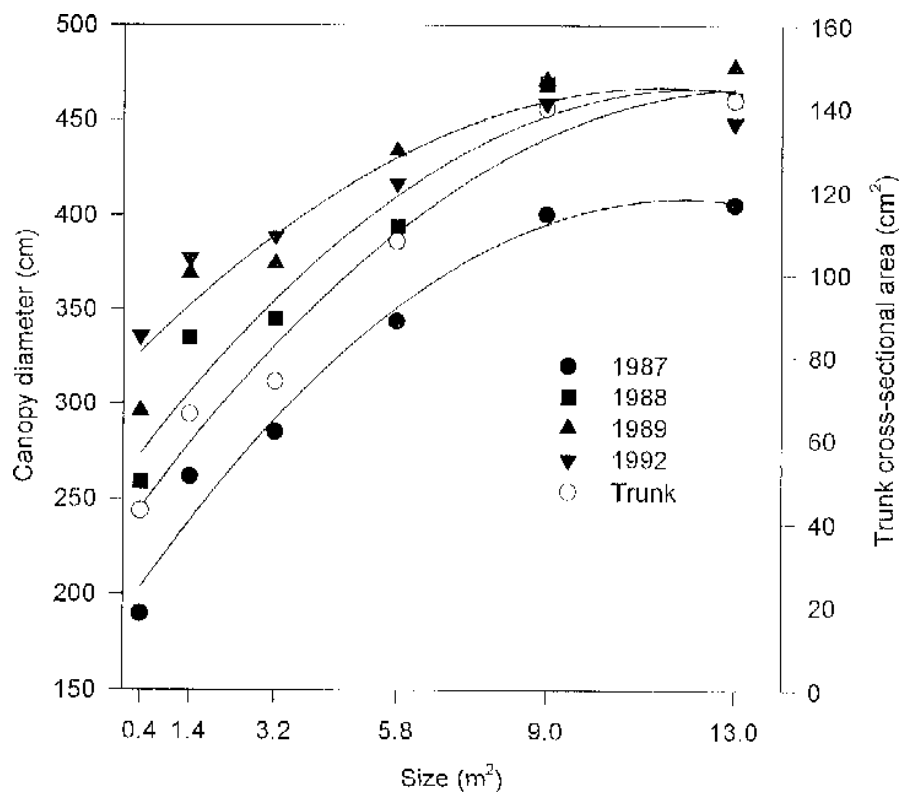

Fig. 1. Relationship between the size of the vegetation-free area and canopy diameter (solid symbols) and trunk cross-sectional area (open symbols). Data for trunk cross-sectional area are the average for 1987-92. Data are averaged over irrigation treatments.

of $100 \mathrm{~cm}$ at planting. The soil type was a Hagerstown silt loam (fine, mixed, Mesic Typic Hapludalf). Six VFA sizes (0.36, 1.4, 3.2, 5.8, 9.0, and $13.0 \mathrm{~m}^{2}$ ) were established as treatments. $N$-(phosphonomethyl)glycine (glyphosate) at $2.2 \mathrm{~kg}$ a.e. (acid equivalent)/ha was applied to kill the sod within the VFAs before planting. A residual herbicide treatment of $N$-(3,4-dichlorophenyl)- $N, N$-dimethylurea (diuron) at $1.12 \mathrm{~kg}$ a.i. (active ingredient)/ha plus 5-chloro-3-(1,1dimethylethyl)-6-methyl-2,4-(1H,3H)-pyrimidinedione (terbacil) at $1.12 \mathrm{~kg}$ a.i./ha was applied once each spring to maintain the VFAs for the entire growing season. The remainder of the field was maintained in K-31 sod that was periodically mowed. The trees were planted 4.5 $\mathrm{m}$ apart in rows $6 \mathrm{~m}$ apart.

In 1987, we established a split plot design with VFA size as the main plot and irrigation as the subplot. The subplot contained one tree, and a border tree separated the main plots. We used three subplot treatments: 1) no irrigation, 2) drip irrigation during stage 3 of fruit development, and 3) fertigation during stage 3 of fruit development. Generally, stage 3 began in late June and harvest was in early August. Each treatment combination was replicated five times. The volume of water applied related to VFA size. Our early work established that tree size was proportional to VFA size and the bare soil-sod interface was the zone of root restriction (Welker and Glenn, 1989). For this reason, the irrigation level of each VFA was proportional to its perimeter. Pan evaporation is about $8 \mathrm{~mm} \cdot \mathrm{d}^{-1}$ during this period. The 0.36- $\mathrm{m}^{2}$ VFA had two $4-\mathrm{L} \cdot \mathrm{h}^{-1}$ emitters, and the number of emitters increased to twelve $4-\mathrm{L} \cdot \mathrm{h}^{-1}$ emitters in the $13.0 \mathrm{~m}^{2}$ square size. Trees were irrigated for $6 \mathrm{~h}, 1 \mathrm{~d} /$ week beginning in early June to ensure root development within the wetted zone. Thereafter, trees were irrigated about $6 \mathrm{~h} \cdot \mathrm{d}^{-1}, 5 \mathrm{~d} /$ week during late stage 2 and throughout stage 3 of fruit development. Bags of fertilizer were placed under each emitter in the fertigation treatments in June. The plastic mesh bags contained $100 \mathrm{~g}$ of a slow-release fertilizer (14-6.12-11.62), and the irrigation water drained through the fertilizer before infiltration into the soil.

We evaluated the cold hardiness of peach shoots in March 1988 and 1989 using the methodology described by Greene (1987). Trunk circumference was measured $30 \mathrm{~cm}$ above ground level at the end of each growing season and was used to calculate trunk cross-sectional area. Canopy diameter was measured at the end of each growing season except 1990 and 1991. Trees were trained to an open-center system and the prunings were weighed each spring beginning in 1989. Nitrogen was measured in fully expanded, midshoot leaves (15 leaves/tree) collected in late July before harvest in all years. Leaves were washed with deionized water, dried at $60^{\circ} \mathrm{C}$, and ground to pass a 40-mesh screen. Leaf $\mathrm{N}$ content was determined using a N analyzer (model FP228; LECO Corp., St. Joseph, Mich.). We determined yield from four to six harvest dates in 1987, 1988, 1991, and 1992. No yield was obtained in 1989 and 1990 because of freeze damage to flower buds.

Analysis of variance was based on a split-split-plot design with five replications. VFA size was the main plot, irrigation treatment was the subplot, and year was the sub-subplot. There were treatment interactions with year. Linear and quadratic regression components were analyzed for significance at $P=0.05$, and differences in regressions were determined using a 95\% confidence interval. When regressions for specific years were not significantly different and a VFA $\times$ year interaction was insignificant, data were pooled for the grouping of years.

\section{Results}

Canopy diameters increased with the increasing VFA size but were not influenced by irrigation treatment (Fig. 1). Canopy diameters increased from $1987\left(\mathrm{y}=191.1+36.4 \mathrm{x}-1.5 \mathrm{x}^{2}, R^{2}=\right.$ $0.82)$ to $1988\left(\mathrm{y}=259.4+34.7 \mathrm{x}-1.4 \mathrm{x}^{2}, R^{2}=0.79\right)$ and there was no difference in canopy diameters for 1989 and $1992(y=318.4+$ $\left.25.8 \mathrm{x}-1.1 \mathrm{x}^{2}, R^{2}=0.62\right)$, indicating a stable canopy volume from 1989 to 1992 . Trunk cross-sectional area increased with increasing VFA size (Fig. 1) with no year $\times$ VFA interaction $(y=45.21+$ $\left.16.65 \mathrm{x}-0.62 \mathrm{x}^{2}, R^{2}=0.92\right)$. Pruning weights increased with increasing VFA size (Fig. 2) and were higher in the dormant season following years without fruit (1990 and 1991, $\mathrm{y}=8.14+3.54 \mathrm{x}-$ $0.14 \mathrm{x}^{2}, R^{2}=0.49$ and $\mathrm{y}=12.28+2.83 \mathrm{x}-0.10 \mathrm{x}^{2}, R^{2}=0.37$,

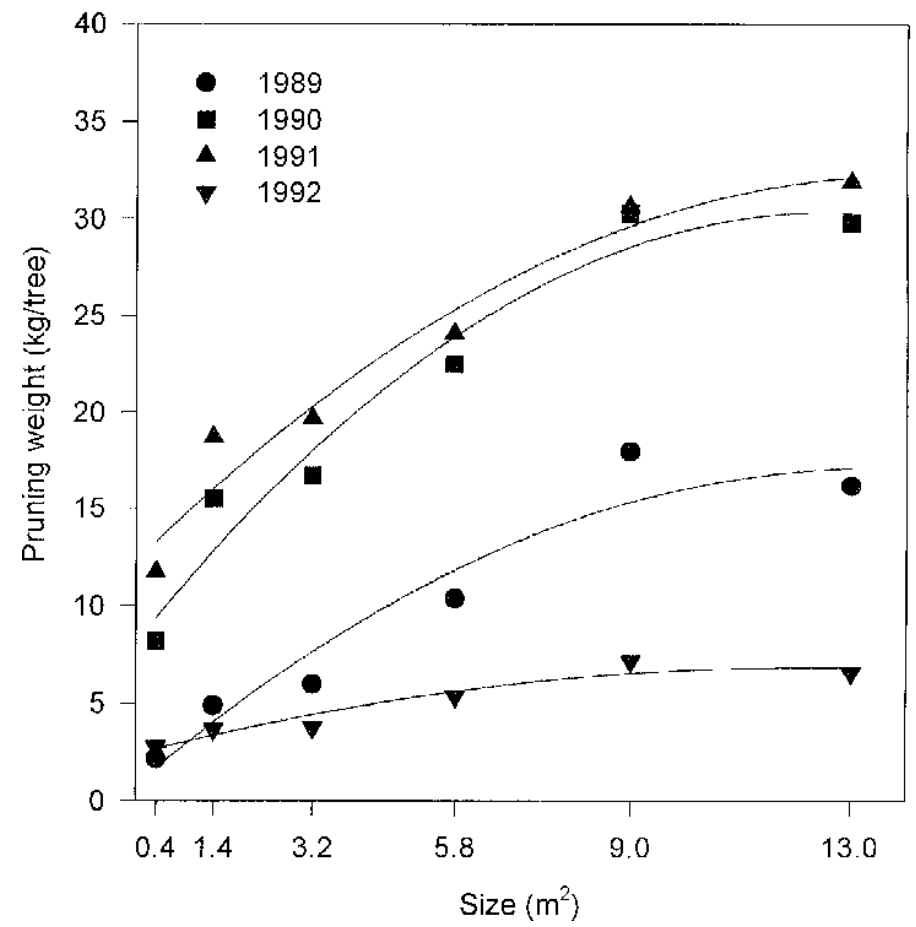

Fig. 2. Relationship between the size of the vegetation-free area and pruning weight for 1989-92 averaged over irrigation treatments. 


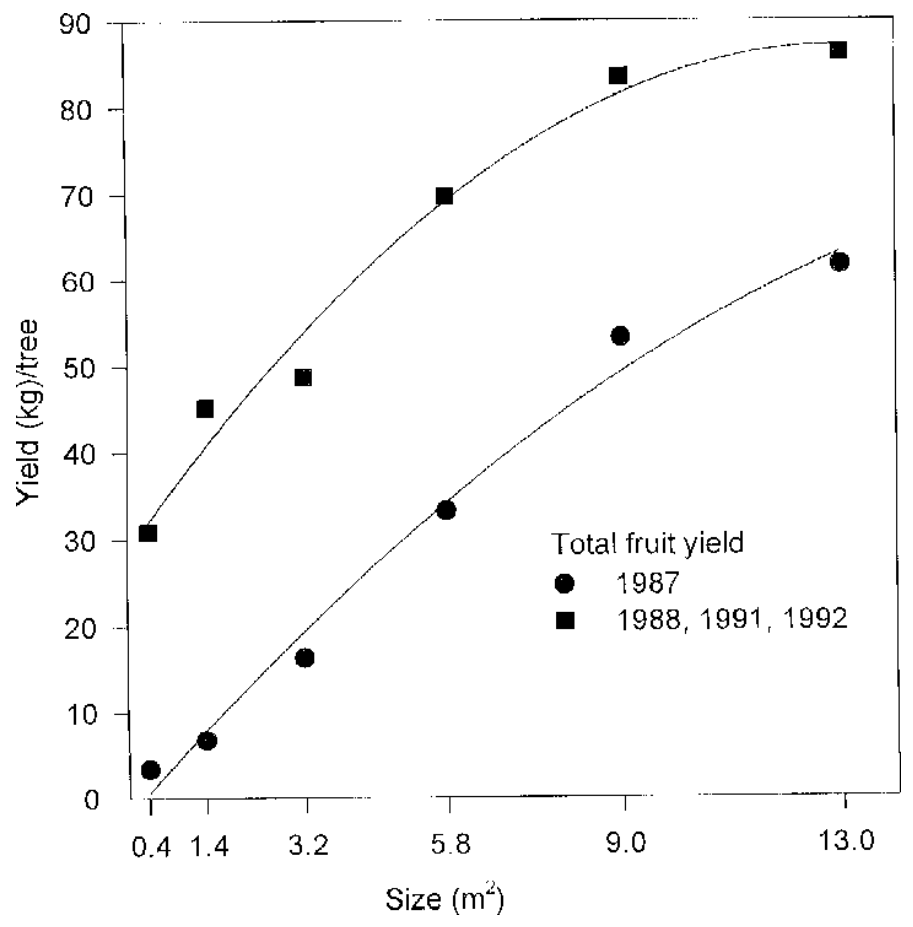

Fig. 3. Relationship between the size of the vegetation-free area and total fruit yield averaged over irrigation treatments.

respectively) than years with a fruit crop (1989 and 1992, $y=0.89$ $+2.40 \mathrm{x}-0.09 \mathrm{x}^{2}, R^{2}=0.54$ and $\mathrm{y}=2.45+0.71 \mathrm{x}-0.03 \mathrm{x}^{2}, R^{2}=0.20$, respectively). Irrigation and fertigation did not significantly affect TCA or pruning weight. The total fruit yield/tree increased with VFA size (Fig. 3). Total yield/tree in $1987(\mathrm{y}=-1.89+7.22 \mathrm{x}-$ $\left.0.17 \mathrm{x}^{2}, R^{2}=0.90\right)$ was less than in 1989,1991 , and $1992(\mathrm{y}=28.78$ $\left.+8.97 \mathrm{x}-0.34 \mathrm{x}^{2}, R^{2}=0.54\right)$. Irrigation and fertigation did not affect total yield/tree in any year. Irrigation and fertigation increased yield of fruit $>75 \mathrm{~mm}$ diameter (large fruit) in 1988, 1991, and 1992 for all VFA sizes $\left(\mathrm{y}=27.90+8.30 \mathrm{x}-0.29 \mathrm{x}^{2}, R^{2}=0.56\right)$ compared to the nonirrigated control treatments $(\mathrm{y}=23.76+7.49 \mathrm{x}-0.33 \mathrm{x} 2$, $\left.R^{2}=0.46\right)$ (Fig. 4). Irrigation and fertigation did not increase yield of large fruit in 1987 (Fig. 4) $\left(\mathrm{y}=-1.88+7.20 \mathrm{x}-0.17 \mathrm{x}^{2}, R^{2}=0.90\right)$. The total yield efficiency and the yield efficiency of large fruit was directly related to VFA size (Fig. 5) in 1987 (y $=0.160+0.073 \mathrm{x}$ $-0.003 \mathrm{x}^{2}, R^{2}=0.67$ for both parameters, respectively), and irrigation treatment did not affect yield efficiency. In 1988, 1991, and 1992 neither VFA size nor irrigation treatment affected total yield efficiency and yield efficiency of large fruit (Fig. 5) (mean of 0.59 and $0.52 \mathrm{~kg} \cdot \mathrm{cm}^{-2}$, respectively). Trees grown in the $0.36-\mathrm{m}^{2}$ VFA had a yield efficiency similar to that of trees in the 3.2- to $13.0-\mathrm{m}^{2}$ VFAs from 1988 to 1992. Similarly, total yield and large fruit yield/amount of pruning weight for 1988, 1991, 1992 were not affected by VFA or irrigation treatment (mean of 9.6 and $8.8 \mathrm{~kg} \cdot \mathrm{kg}^{-1}$ ).

Leaf $\mathrm{N}$ levels were $>2.5 \%$ throughout the study in all VFAs. Although leaf $\mathrm{N}$ was not related to VFA size, irrigation and fertigation increased $(P=0.05)$ leaf $N$ over the control (fertigation, $2.84 \%$; irrigation, $2.80 \%$; and control treatments, $2.70 \%$ ).

The analysis of cold hardiness in 1988 and 1989 indicated that VFA size and irrigation treatment did not affect electrical conductivity of diffusates from frozen plant samples (data not presented). Fertigation treatment was not significantly different from the irrigation treatment for yield and growth parameters.

\section{Discussion}

Our study demonstrated that a sod barrier can restrict the growth of peach trees presumably by reducing the effective size of the peach root system. Earlier work by others demonstrated that physical containment of the root system will reduce plant size by restricting the development, physiology, and extent of the root system (Carmi and Heuer, 1981; Hameed et al., 1987; Nesmith et al., 1992; Richards and Rowe, 1977; Rieger and Marra, 1994; Williamson et al., 1990, 1992). Our earlier work (Glenn and Welker, 1989, 1993) demonstrated that fine root development in sod is restricted when water is limiting; therefore, VFA size limits the volume of soil in which water and nutrients are exclusively available to the peach tree. In addition, Parker et al. (1993) demonstrated that peach rooting into tall fescue is restricted. Irrigation and fertigation increased fruit size in 1988, 1991, and 1992 but did not increase tree growth, due to the short period of time water was applied (4 to 6 weeks), and stage 3 of fruit development is a time of carbon partitioning to fruit, not wood. These results suggest that root function in the VFAs is not reduced, since large fruit yield is increased by irrigation and fertigation. Irrigation during stage 3 , then, will not result in a resumption of excessive tree growth and will increase fruit size.

Controlling tree size maintained high yield efficiency in our study as in others (Boland et al., 1994; Myers, 1992; Williamson and Coston, 1990), supporting the idea that using physical and biological root confinement can achieve productive, high-density peach orchards. Williamson and Coston (1990) found that reducing the herbicide strip from 1 to $0.5 \mathrm{~m}$ reduced yield efficiency. Their data were for the first fruiting year, and our study also shows that early yield efficiency is reduced. When trees matured, yield efficiency and yield/unit pruning weight were not reduced by smaller VFAs in the present study. Yield efficiencies of total and large fruit were not increased by irrigation or fertigation in contrast to a significant increase in total and large fruit yield with no

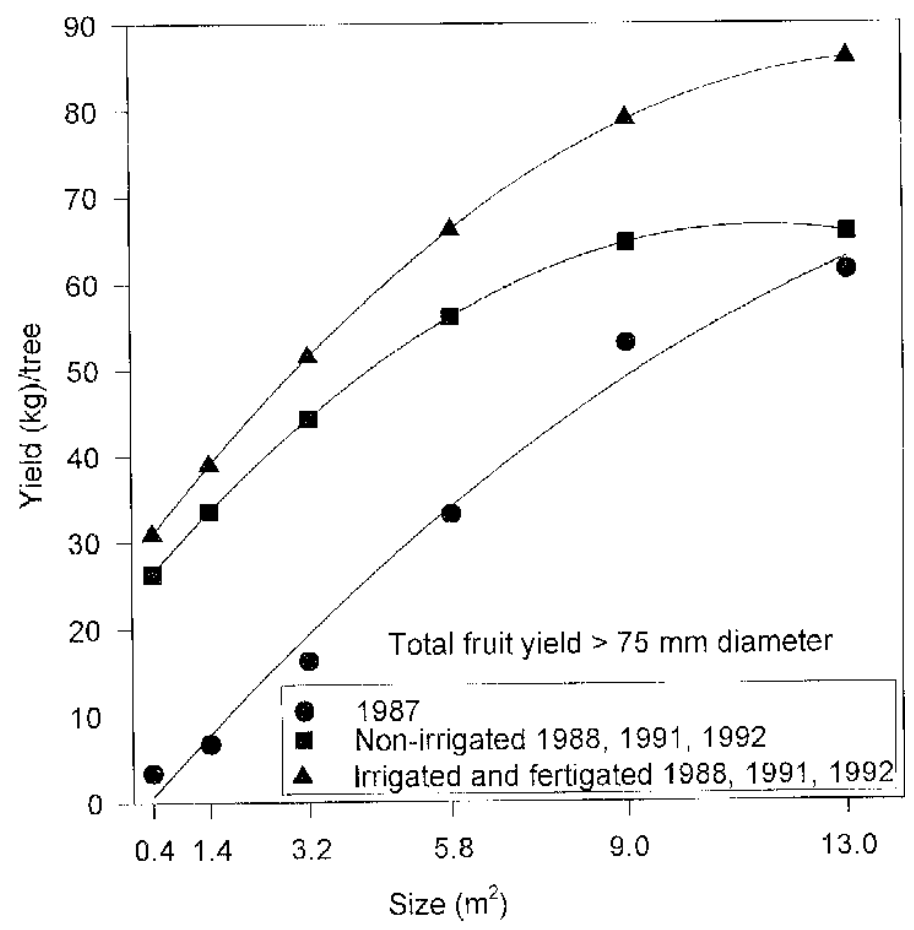

Fig. 4. Relationship between the size of the vegetation-free area and yield of fruit $>75 \mathrm{~mm}$ in diameter. Data for 1987 are averaged over irrigation treatments. 


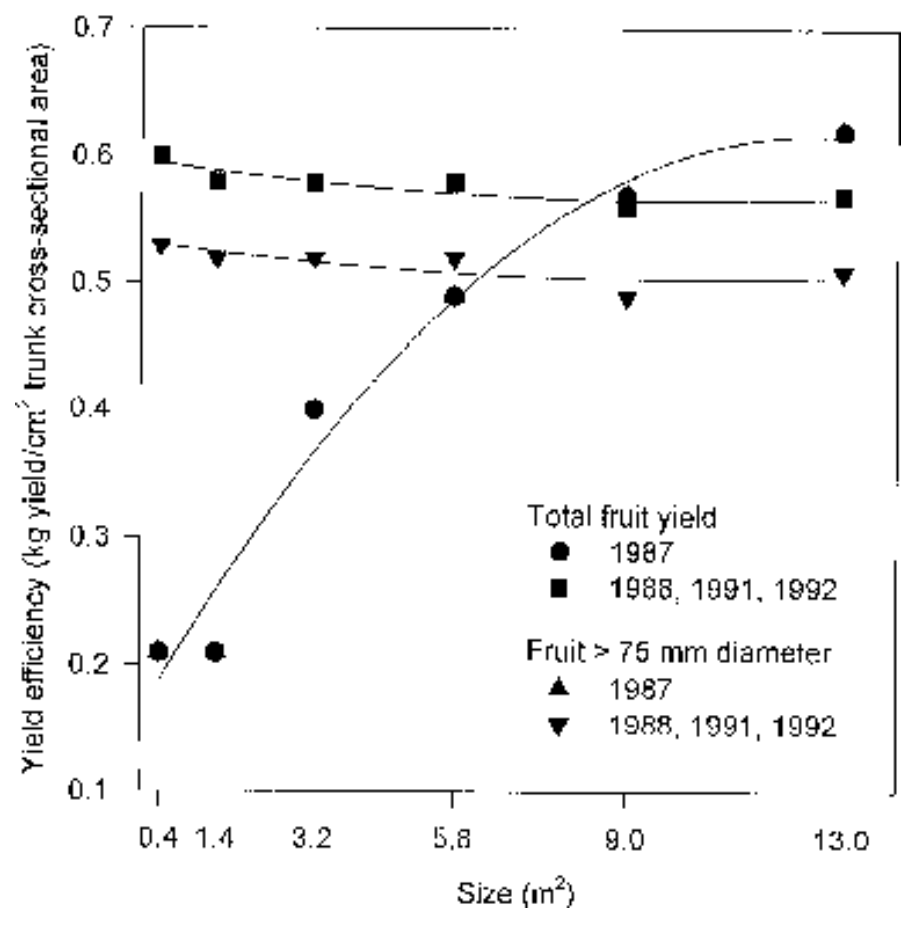

Fig. 5. Relationship between the size of the vegetation-free area and yield efficiency for total fruit yield and yield efficiency of large fruit. Data are averaged over irrigation treatments.

significant effect of irrigation and fertigation on trunk diameter. The lack of a significant effect of irrigation and fertigations on yield efficiency is probably due to variability within the data.

Sod management effectively controlled tree size and maintained high yield efficiency on our highly productive study site. Our site contained a deep, well-drained, fertile soil that was at field capacity in the spring and received an average of $371 \mathrm{~mm}$ precipitation during the May to September growing season. A parallel, long-term study of root pruning peaches on this soil demonstrated that even monthly root pruning before stage 3 of peach development could not control tree size (Glenn and Miller, 1995). Cold hardiness was not influenced by VFA size or irrigation treatment and supports Edgerton's work (1960) that permanent groundcovers, per se, do not influence cold hardiness of healthy, vigorous trees on fertile soil.

We conclude that sod management of peaches can effectively control peach tree size. It costs less than installing permeable fabric (Myers, 1992; Williamson and Coston, 1990), allows the use of adapted rootstocks, and may provide flexibility in the degree of root containment when the proximity of sod to the tree is balanced with the depth and fertility of the soil. Sod management, together with irrigation, may facilitate increased productivity of highdensity peach plantings.

\section{Literature Cited}

Bargioni, G., F. Loreti, and P.C. Pisani. 1983. Performance of peach and nectarine in a high density system in Italy. HortScience 18:143-146.

Boland, A.M., P.D. Mitchell, I. Goodwin, and P.H. Jerie. 1994. The effect of soil volume on young peach tree growth and water use. J. Amer. Soc. Hort. Sci. 119:1157-1162.

Bradford, F.C. and H.A. Cardinell. 1926. Eighty winters in Michigan orchards. Spec. Bul. 149. Agr. Expt. Sta. Mich. State College.

Carmi, A. and B. Heuer. 1981. The role of roots in control of bean shoot growth. Ann. Bot. 48:519-527.
Chalmers, D.J., P.D. Mitchell, and L. van Heek. 1981. Control of peach tree growth and productivity by regulated water supply, tree density, and summer pruning. J. Amer. Soc. Hort. Sci. 106:307-312.

Chandler, W.H. 1954. Cold resistance in horticultural plants: A review. Proc. Amer. Soc. Hort. Sci. 64:552-572.

Cooper, J.R. 1953. Factors affecting winter injury to peach trees. Bul. 536. Agr. Expt. Station. Univ. Ark. College, Fayetteville.

Crane, H.C. 1930. Physiological investigations on the resistance of peach bud to freezing temperatures. Bul. 326. Agr. Expt. Sta., West Virginia Univ.

Dozier, W.A. Jr. 1984. Survival growth and yield of peach trees as affected by rootstocks. HortScience 19:26-30.

Edgerton, L.J. 1960. Studies on cold hardiness of peach trees. Bul. 958. Cornell Univ. Agr. Expt. Sta., Ithaca, N.Y.

Giulivo, C., A. Pomina, and G. Costa. 1984. Effects of planting density on peach and nectarine productivity. J. Amer. Soc. Hort. Sci. 109:287-290.

Glenn, D.M. and S.S. Miller. 1995. Growth yield and water use responses of peach to repeated root pruning. HortScience 30:543-546.

Glenn, D.M. and W.V. Welker. 1989. Peach root development and tree hydraulic resistance under tall fescue sod. HortScience 24:117-119.

Glenn, D.M. and W.V. Welker. 1993. Water transfer diminishes root competition between peach and tall fescue. J. Amer. Soc. Hort. Sci. 118:570-574.

Gradziel, T.M. and W. Beres. 1993. Semi-dwarf growth habit in Clingstone peach with desirable tree and fruit qualities. HortScience 28:1045-1047.

Greene, G.M. 1987. Proposed standard procedures for electrical conductivity measurements of winter hardiness of deciduous fruit crop shoots. Proc. Cumberland-Shenandoah Fruit Workers Mtg. Harpers Ferry, WV.

Hameed, M.A., J. B. Reid, and R.N. Rowe. 1987. Root confinement and its effects on the water relations, growth, and assimilate partitioning of tomato (Lycopersicon esculentum Mill). Ann. Bot. 59:685-692.

Hayden, R.A. and F.H. Emerson. 1973. Close ranks for more peaches. Amer. Fruit Grow. (Dec.):13-15.

Huslig, S.M., M.W. Smith, and G.H. Brusewitz. 1993. Irrigation schedules and annual ryegrass as a ground cover to conserve water and control peach tree growth. HortScience 28:908-913.

Hutton, R.J., L.M. McFadyen, and W.J. Lill. 1987. Relative productivity and yield efficiency of canning peach trees in the intensive growing systems. HortScience 22:552-560.

Layne, R.E.C. 1987. Peach rootstocks, p. 185-216. In: R.C. Rom and R.F. Carlson (eds.). Rootstocks for fruit crops. Wiley, New York.

Miller, S.S. 1988. Plant bioregulators in apple and pear culture. Hort. Rev. 10:309-401.

Myers, S.C. 1992. Root restriction of apple and peach with in-ground fabric containers. Acta. Hort. 322:215-219.

Nesmith, D.S., D.C. Bridges, and J.C. Barboar. 1992. Bell pepper responses to root restriction. J. Plant Nutr. 15:2763-2776.

Parker, M.L., J. Hull, and R.L. Perry. 1993. Orchard floor management affects peach rooting. J. Amer. Soc. Hort. Sci. 118:714-718.

Phillips, J.H.H. and G.M. Weaver. 1975. A high density peach orchard. HortScience 10:580-582.

Ran, Y., B. Bar-Yosef, and A. Erez. 1992. Root volume influence on dry matter production and partitioning as related to nitrogen and water uptake rates by peach trees. J. Plant Nutr. 15:713-726.

Richards, D. and R.N. Rowe. 1977. Effects of root restriction, root pruning, and 6-benzlominopurine on the growth of peach seedlings. Ann. Bot. 41:729-740.

Rieger, M. and F. Marra. 1994. Responses of young peach trees to root confinement. J. Amer. Soc. Hort. Sci. 119:223-228.

Rom, R.C. 1983. The peach rootstock situation: An international perspective. Fruit Var. J. 37:3-14.

Scorza, R. 1984. Characterization of four distinct peach tree growth types. J. Amer. Soc. Hort. Sci. 109:455-457.

Welker, W.V. and D.M. Glenn. 1985. The relationship of sod proximity to the growth and nutrient composition of newly planted peach trees. HortScience 20:417-418.

Welker, W.V. and D.M. Glenn. 1989. Sod proximity influences the growth and yield of young peach trees. J. Amer. Soc. Hort. Sci. 114:856-859.

Williamson, J.G. and D.C. Coston. 1990. Planting method and irrigation rate influence vegetative and reproductive growth of peach planted at high density. J. Amer. Soc. Hort. Sci. 115:207-212.

Williamson, J.G., D.C. Coston, and J.A. Cornell. 1992. Root restriction affects shoot development of peach in a high-density orchard. J. Amer. Soc. Hort. Sci. 117:362-367. 